\title{
Ev Kadınlarının Turizm Amaçlı Yöresel Yemek Üretimine Bakış Açıları: Bartın İli Örneği
}

\author{
Nurettin Ayaz ${ }^{a^{*}}$, Sibel Çobanoğlu ${ }^{b}$ \\ aKarabük Üniversitesi, Safranbolu Turizm Fakültesi, Karabük. \\ ${ }^{b}$ Karabük Üniversitesi, Sosyal Bilimler Enstitüsü, Karabük.
}

\begin{abstract}
Öz
Gastronomi ve kültür turizmi kapsamında seyahate çıkan turistlerin seyahat nedenleri arasında yöresel yemeklerde yer almaktadır. Bununla birlikte turistler birçok destinasyonda yöresel yemekleri deneyimleme konusunda sikıntılar (estetik, lezzet, kalite, hijyen, fiyat) yaşamaktadır. Bu sıkıntıların aşılmasında yöresel yiyecek hizmeti sunan işletmelerinin nicel ve nitel açıdan yeterli hale getirilmeleri gerekmektedir. Bu araştırmada ev hanımlarının turistler için yöresel yemek üretme konusundaki bakış açılarının ortaya çıkarılması ve turizme kazandırılması amaçlanmaktadır. Bu amaç doğrultusunda kültür ve deniz turizminde önemli bir varış noktası olan Bartın ilinde ikamet eden 420 ev kadınından anket tekniği ile veri toplanmıştır. Verilerin analizi sonucunda ev kadınlarının yöresel yemeklere yönelik tutumlarının üretim, eğitim, girişimcilik ve menü alt boyutlarında şekillendiği saptanmıştır. Ayrıca il özelinde ev kadınlarının bakış açısıyla Bartın ili yöresel yemeklerine yönelik bir sınıflandırma yapılmıştır.
\end{abstract}

Anahtar Kelimeler: Turizm, yöresel yemek, ev kadınları, bakış açısı, Bartın.

\section{The Views of Housewives towards Touristic Local Food Production: The Case of Bartın Province}

\begin{abstract}
The travel reasons of tourists, who travel on gastronomy and cultural tourism, are local foods. However, in many destinations about experiencing of local foods, tourists encounter some problems (aesthetics, taste, quality, hygiene, price). In overcoming these troubles local food service providers' need to be made sufficiently qualitative and quantitative. the purpose of this study is to reveal housewives' viewpoints about producing local dishes for tourists and to inclusive them to tourism. For this purpose, data were collected from 420 housewives, lived in Bartm, an important destination of culture and coastal tourism, by surveying method. according to result of the analysis, it has been determined that the attitudes of housewives towards local foods are shaped by the production, education, entrepreneurship and menu sub-dimensions. In addition, a classification for the local dishes of Bartm province was made in terms of the view of housewives.
\end{abstract}

Keywords: Tourism, local dishes. housewives, viewpoint, Bartın.

\section{Gíriş}

Bir bölgede turizmin gelişimi için turistlerin deneyimin temel bir parçalarından bir tanesini de yöresel yiyecekler oluşturur. Sürdürülebilir turizmde pratikler ve ürünler oluşturmada oldukça etkili olan yöresel yiyeceklerin turizmde kullanılması, zengin turistler için çekiciliğinin ayrılmaz bir parçasıdır. Yöresel yiyecekler; destinasyon özelliklerini farklılaştırma, ziyaretçi sayısını artırma, sürdürülebilir istihdam geliştirme ve destinasyondaki diğer ekonomik sektörlerin uyarılmasında da etkilidirler. Bu nedenlerle bir destinasyonda yöresel yiyeceklerin teşviki, kültürel miras 
özelliklerinin yaşatılması önem arz eder (Amira, 2009; Tayfun ve Tokmak, 2007). Özellikle eko-gastronomi kapsamında yerel yiyecek üretimini ve ev yemekleri yapımını yaşatmak, yerel mutfak bilgilerini gelecek kuşaklara aktarmak, çocuklara lezzet eğitimi vermek, mutluluk ve çeşitlilik hakkı sağlamak yer almaktadır. Ayrıca turistleri ziyaret ettiğini topluluğun üyesiymiş gibi hissettirmek için çevreye duyarlı olarak yiyecek üretmektir (Yurtseven ve Kaya, 2011).

Artan rekabet ortamında destinasyonların çekiciliğini artırabilecek farklı turizm çeşitlerine olan ihtiyaç, gün geçtikçe daha da artmaktadır (Aslan vd., 2014: 4). Rekabetin sağlanabilmesi ve destinasyonlar için sürdürülebilirliğin oluşturulabilmesi için her destinasyon kendine özgü ivmelerle turizmini canlandırmayı sağlamalıdır. Bu değerlerden bir tanesi de yöresel yiyeceklerin ön plana çıkarılarak değişen turizm trendlerine cevap bulunması sağlanmasıdır. Bu bağlamda destinasyonun çekiciliğini arttırmak için farklı turizm çeşitlerine ek olarak yöreye ait yiyecek ve içeceklerin turizm ürünü olarak kullanılmaya başlanması gerekmektedir. Hatipoğlu vd. (2013: 6) göre yöresel yemekler; bir şehir veya yöre de insanların yıllar boyunca birlikte yaşamalarının bir sonu olarak, gelenek haline gelmiş, özel günlerde daha fazla tüketilen, genelde bir olay sonucunda kültüre yerleşmiş ve halk tarafından diğer yemeklerden üstün tutulan yiyecekler olarak tanımlanmaktadır.

Günümüzde yerel yiyecekler ve içecekler turistlerin destinasyon seçiminde ana motivasyon kaynağı olmasa da son yıllarda yerel mutfakların turistlerin destinasyon seçiminde artan motivasyon kaynaklarından olduğu dikkat çekmektedir (Bezirgan ve Koç, 2014: 928). ABD'de 1994 yılında 1.775 adet olan yerel pazar sayısının 2010 yılına gelince 6.132'ye çıkarak \%245,5 artması yerel organik ürünlere verilen önemin arttığının bir göstergesidir. Yiyecek ve içecek kültürü tüm turizm şekilleri ile ilişkilendirilebilir. Bununla birlikte destinasyon çekiciliğini arttıran bir kültürel tanıtım aracı olarak da nitelendirilebilir. Zengin yiyecek ve içecek kültürüne sahip Türkiye bu avantajını çok fazla alanda değerlendirebilir (Kesici, 2012: 34).

Turistler tatilleri boyunca yöreye özgü kültürel değerleri, yerel halkın günlük yaşam biçimini, yöresel yemek kültürlerini, yöresel kıyafetleri, gelenekler-görenek ve el sanatları gibi konularda bilgi edinmek istemektedir. Bu nedenle kırsal turizm alanlarını tercih etmektedir. Genellikle kırsal turizm işletmesi olarak adlandırılan, çiftlik evi, köy evi, yayla evi ve dağ evinde konaklamaktadır (Hatipoğlu vd., 2013: 7). Ayrıca turistler gittikleri destinasyonların mutfaklarını merak etmekte ve yöresel yemekleri sunan restoranları tercih etmektedir. Yabancı turistler açısından bakıldığında da ülke tanıtımında etkili olan mutfak kültürü sayesinde turistlerin ilgili ülkeyi tercih etmesi sağlanacaktır (Aslan vd., 2014: 4).

Destinasyonların sahip oldukları yerel mutfaklar, turistlerin tatil kalitelerini arttırmada önemli bir etkiye sahiptir. Turistlerin her ne nedenle seyahat ederse etsin yerel mutfaklar; turizm destinasyonunun profilini yükseltmek, yeni iş imkanlarını yaratmak ve bölgesel kalkınmayı desteklemesi adına oldukça önem arz etmektedir (Bezirgan ve Koç, 2014: 928). Yöresel yemeklerin ait oldukları yörenin bir parçası ve yörenin kültür hakkında fikir edinmenin bir aracı olarak önemli bir öğedir. Turistlerin 
yöresel yemekleri görmeleri ve tatmaları durumunda destinasyonun çekiciliği artacağ (Zağralı ve Akbaba, 2015) gerçeğine rağmen yöresel yemekler, ticarileşme boyutu başta olmak üzere lezzet, kalite, turistik sunum, fiyat, kalite ve bu yemekleri sunuma hazır hale getirecek üretici kişiler boyutunda sıkıntılar yaşanmaktadır.

$\mathrm{Bu}$ araştırmada Batı Karadeniz Bölümünde yer alan ve önemli bir çekicilik merkezi olan Amasra destinasyonundaki ev kadınlarının yöresel yemeklere bakış açıları üzerine bir anlayış geliştirilmesi, destinasyonda yöresel yemek satışı yapan işletme sayısının artırılması ve ev kadınları düzeyinde farkındalık oluşturarak istihdam alanlarının genişletilmesi hedeflenmektedir.

\section{Literatür Taraması}

Kültürel çekicilik bağlamında seyahat gerçekleştiren bir turistin ziyaret ettiği bölgenin kültürünü deneyimleme sürecinde yöresel yiyecekler ve mutfak önemli bir role sahip bulunmaktadır. İnsanların temel ihtiyaçlarından bir tanesi olan beslenme gereksinimi kapsamında hemen hemen tüm turistler yöresel yiyeceklerle bir şekilde buluşmakta ve yemekleri duyusal zevk etkinliği olarak öne çıkmaktadırlar (Chang vd., 2010).

Bir bölgeye ait yiyecek ve içecek türleri, bu yiyecek ve içecekleri tüketme alışkanlıkları "yemek kültürü" kavramı ile açıklanmakta ve destinasyonların pazarlanmasında yerel yiyecek ve içeklerin ön plana çıkarılması ve keşfedilmemiş yemek kültürlerinin varlığına dikkat çekilmektedir (Ballı, 2016). İnsanların açlık hissini giderebilecek yiyecek ve içeceklerin toplumsal inanış ve geleneklerle hazırlanması, pişirilmesi, saklanması ve sunulması şeklinde ortaya çıkan süreçlerle ilişkilendirilen yerel yemek kültürünün her ülke veya bölge düzeyinde toplumsal davranış ve alışkanlıklar çerçevesinde değiştiği öngörülmektedir. Türkiye'de hayvancılık işkolu ile öne çıkan Doğu Anadolu Bölgesi için yöresel yemeklerinin tümünde et kullanılması, genel geçim kaynağı balıkçılık olan Karadeniz Bölgesi içinse yemek kültüründe balığın ön planda yer alması somut örnekler olarak gösterilmektedir (Sağır, 2012; Serçeoğlu, 2014: 38).

Yiyeceklerin üretimi, tüketimi ve hazırlanması tamamen kültürün bir öğesidir (Aslan, 2010: 33). Bir yörede bu öğeden söz edilebilmesi için yöreye ait mutfak kültürünü yaşatabilen insanlara ihtiyaç bulunmaktadır. Bu insanlar içinde yaşadıkları coğrafyanın doğal koşulları ile bilgi, beceri, deneyim ve geleneklerini birleştirebilen ve tükettikleri yiyecek ve içeceklere yansitabilen kişilerdir. Bu anlamda bir toplumun yemek kültürü için öne çıkarılması gereken insan unsuru kadınlardır. İlk etapta aileleri için yiyecek ve içecekler hazırlayan kadınlar zaman içersinde turizm gibi yeni işkolları ile turistler içinde yiyecek ve içecekler hazırlar hale gelmişlerdir. Ancak bu oran erkeklere göre oldukça düşüktür.

Birleşmiş Milletler (UN) ve Dünya Turizm Örgütü'ne (UNWTO) göre turizm, kadınların güçlendirmesine yardımcı olabilecek işkollarından bir tanesidir. Kadınların turizm sektöründe güçlendirilmesi, kırsal yoksulluğun azaltılması ve daha fazla 
ekonomik büyüme için bir fırsat olup, kadının toplumsal farkındalığını ve saygınlığını artırma açısından da önemlidir (Alsawafi, 2016).

Turizm sektörüne yönelik işkollarında kadınların değişim ve ziyaretçilerle ilişkilerde daha uyumlu olmaları, iletişim becerileri, ziyaretçilerin talep ve isteklerini daha iyi anlayabilmeler, iş birliği ve birlikte çalışmaya yatkınlıkları ve işlerini ciddiye almaları başarı unsurları olarak sıralanmaktadır (Fidan ve Nam, 2012). Bununla birlikte kadının içinde bulunduğu toplumun muhafazakâr gelenek ve göreneklerinin etkisiyle turizm sektörü işlerinde çalışmasının olumsuz algılanması, turizm sektöründe çalışmayı seçmelerini engelleyen en önemli zorluk olarak gösterilmektedir (Alsawafi, 2016).

Turizm sektöründe değişen turist profili kapsaminda destinasyonlar kültürel değerleri daha fazla önemsemeye başlamışlar ve kültürel öğeleri daha fazla deneyimleye ve seyahat motiflerini değiştirmeye başlamışlardır. Bu süreçte turizmde başarılı destinasyonlar kültürel ve geleneksel değerlerine öne çıanlar olmaya başlamıştır (Cömert, 2014). İnsanların yaşadığı toplumsal özellikleri ve emekleri ile şekillenen geleneksel mimari, dinsel motifler, yerleşme, arazi kullanımı, kılık kıyafet tarzı, el sanatları, müzik ve yemekler turistler için sıkça talep edilen çekicilikler haline gelmiştir (Emekli, 2006; Öter ve Özdoğan, 2005). Dünya Turizm Örgütü raporuna göre, Avrupalıların \%22'sinin tatile gidişlerinin temel nedeni; kültürel deneyim olduğu belirlenmiştir (Gheorghe vd., 2014: 13).

Bir turizm bölgesinde bazen açlığını gidermek için bazen de farklı deneyimleri tecrübe etmek ve yeni lezzetler tatmak amacıyla ortaya çıkabilen yemek yeme ihtiyacı, o bölgenin kültürünün bir parçası (Shenoy, 2005) ve bilimsellik ve sanat unsurları kapsamında yiyecek ve içeceklerin hazırlanmasını ve çağın gerektirdiği şartlarına uyarlanmasını öngören çalışmalarını kapsayan gastronominin (Hatipoğlu, 2010) önemli öğesidir.

Kültür turizminin önemli bölümünü oluşturan yöresel mutfağın turizme katkısı oldukça fazladır. Bu durumun temel nedeni seyahat edenlerin büyük çoğunluğunun yeme ve içme eylemini diğer aktivitelerden üstün tutmalarıdır. Bu anlamda yöresel yemekler, mutfak turizmi kapsamında destinasyonlara taşınmalıdır (Okech, 2014). Bununla birlikte yöresel mutfak ürünlerini tüketme, farklı gelenek ve görenekleri deneyimleme ve yöredeki farklı yerleri ziyaret etme eğilimleri ile öne çıkan gastronomi turistleri de destinasyon için önemli bir ekonomik kaynaktır (Gheorghe vd., 2014).

Turizm sektöründe değişen turist motivasyonları mevcut turizm talebini değiştirir hale gelmiştir. Bu anlamda destinasyonlar otantik ve eşsiz tatil deneyimlerine odaklanır hale gelmektedir (Türker ve Alaeddinoğlu, 2016). Yöresel yemekler, turizm sektöründe gastronomi ve kültür turizmi kapsamında önemini her geçen gün artmaktadır (Gürbüz, 2002). Özellikle gastronomi turizmi kapsamında doğru bir yatırım aracı olarak kullanılabilmesi halinde gelecekte önemli bir ekonomik kaynak ve rekabet üstünlüğü sağlayabilir (Bekar ve Belpınar, 2015). Kültür turizmi kapsamında turistlere yemek aktivitelere katılma imkanı sunulması (Buczkowska ve Poznań, 2014) yöresel yemeklerin turizm kapsamında geliştirilmesi ve lezzetlerle turistlerin 
buluşturulması adına alternatif kaynakların kullanılması gerekmektedir. Bir gelenek olarak kuşaktan kuşağa aktarılan yöresel yemekler için ev kadınları önemli bir paydaş olarak görülebilir. Ev kadınlarının yöresel yemeklere yönelik tecrübeleri ile turist memnuniyeti artırabilir.

\section{Metodoloji}

$\mathrm{Bu}$ araştırma, gastronomi ve kültür turizmi için temel bir gereklilik olarak gösterilen yöresel yemeklerin ev kadınları perspektifinden değerlemesini öngören bir saha çalışması üzerine kurulmuştur. Çalışmada, ev kadınlarının yöresel yemeklerini tanıma ve turistler için yöresel yemek hazırlama eğilimlerine odaklanılmıştır.

\subsection{Araştırma Alanı}

Ev kadınlarının turizm işletmeleri için yöresel yemek üretimine yönelik bakış açılarının belirlenmesini amaçlayan bu çalışmada araştırma alanı olanı olarak Bartın ili seçilmiştir. Bartın ili geçmişinden günümüze taşıdığı seçkin tarihi (Paphlagonia bölgesindeki antik kentler olan Sesamos (Amasra), Kromna (Kurucaşile) ve Erythinoi (Çakraz) Bartın ilinde yer almaktadır.) kültürel ve doğal güzellikleri ile turizm için önemli bir cazibeye sahiptir. Özellikle antik değerlerin en fazla görüldüğü kent konumuyla Amasra kültür ve deniz turizmi kapsamında bir çekim merkezi konumundadır. Son dönemlerde bu çekim merkezine İnkumu ve Çakraz'ın da eklenmesiyle Bartın ilinde turizm önemli bir kolu haline gelmektedir. Turizm hareketliliğinin bir sonucu olarak ilde yaşanan hızlı toplumsal değişime rağmen yerel gelenek ve görenekler, halk oyunları ve müzik, giyim tarzları, el sanatları, mutfak kültürü ve yöresel şive hala kendisini korumaktadır. İnanışlar, gemi atması töreni, yöresel giyim-kuşam, el işlemeleri, tel kırma, dokumacılık, ağaç oymacılığ 1 (çekicilik), gemi yapımcılığı, taş sac yapımı, yöre mutfağı, yerel etkinlikler ve kutlama günleri gibi aktiviteler kültür hayatının vazgeçilmez parçaları olarak sürdürülmektedir (http://www.bartin.gov.tr/kültür-turizm).

Bartın mutfağ ile ilgili olarak yapılan araştırmalarda tespit edilen 100'den fazla yemek çeşidinin olması yöre mutfağının zenginliğini açıcça ortaya koymakla birlikte kentleşmenin etkisiyle daha fazla olan yemek çeşitliği unutulmaktadır (Sözbir, 2010: 175). Bununla birlikte Bartın'ın yöresel yemekleri: pumpum çorbası, pirinçli mantı, çiğ börek, gartlaç, çöven ekmeği, kırtıl, halışka, yumurtalı ısbıt, sütlü armut, gelin teli, beyaz baklava, kabak burması, 20 çeşit malzemesi ile amasra salatası, ovmaç çorbası, öğre çorbası, kesme çorbası, kıymalı ıslama, halışga, cimcik makarna, kuru yufkadan tavuklu börek, maydanoz dolması, kırmızı tarhana, etli mısır çorbası, zarbana tatlısı, fesleğenli gözleme siralanmaktadır.

"Bartın İli Turizm Eylem Planı 2012-2017" çalışmasında ilin güçlü yanları içerisinde \%46 oranla Amasra ilk sirada ve \%31 oranla önemli bir yöresel yemek olarak kabul edilen Amasra Salatası ikinci seyahat önceliği olarak gösterilmektedir. Halihazırda Bartın ilinde toplam 65 kişi kapasiteli özel işletme şeklinde olmak üzere toplam iki adet turizm amaçlı yöresel yemek sunumu yapan tesis bulunmaktadır. 


\subsection{Araştırmanın Amacı, Önemi ve Hipotezleri}

Destinasyonlar için rekabet üstülüğü oluşturmada öne çıkarılabilecek unsurlar arasında yöresel yemeklerin varlığı, çeşitliliği, üretimi ve sunumu sıkça öne çıkarılır hale gelmektedir. Yöresel yemeklerin turizme kazandırılmasına yönelik araştırmalar artmaktadır. Bu araştırmada sahil turizmi kapsamında öne çıan ve Safranbolu ile entegrasyonlu kültürel geziler son zamanlarda kültür turizminde de öne çıkmaya başlayan Bartın ilindeki ev hanımlarının kentlerini ziyaret eden turistler için yöresel yemek üretme konusundaki tutumlarının ortaya çıkarılması ve turizme kazandırılması amaçlanmaktadır. Çalışma, Türkiye'de dezavantajlı gruplar arasında gösterilen ev kadınlarına istihdam sağlamada farkındalık oluşturma ve Bartın ili yöresel yemeklerini tanıtılması ve korunması boyutlarıyla önem arz etmektedir.

Ev kadınlarının yöresel yemeklere yönelik bakış açısının bağımlı değişken, demografik ve diğer özellikleri bağımsız değişken olarak kabul edildiği bu araştırmada şu hipotezin test edilmesi öngörülmüştür:

$\mathrm{H}_{1}$ : Ev kadınlarının medeni durumları ile yöresel yemeklere bakış açıları arasinda anlamlı bir farklılık vardır.

$\mathrm{H}_{2}$ : Ev kadınlarının yaşı ile yöresel yemeklere bakış açıları arasında anlamlı bir farklılık vardır.

$\mathrm{H}_{3}$ : Ev kadınlarının eğitim durumu ile yöresel yemeklere bakış açıları arasında anlamlı bir farklılık vardır.

$\mathrm{H}_{4}$ : Ev kadınlarının yöresel yemek pişirme sıklığ1 ile yöresel yemeklere bakış açıları arasında anlamlı bir farklılık vardır.

H5: Ev kadınlarının turistler için yemek pişirme düşüncesi ile yöresel yemeklere bakış açıları arasında anlamlı bir farklılık vardır.

\subsection{Araştırmanın Evreni ve Örneklem}

Araştırmanın evreni için "Seçilmiş Göstergelerle Bartın 2013" çalışması içerisinde yer almakta olan 51.443 evli, 2.326 boşanmış ve 9.786 eşi ölmüş olmak toplam 63.555 kadın olarak belirlenmiştir. Araştırmada katılımcı sayısının fazlalığıı, zaman ve maliyet unsurları nedeniyle araştırmada örnekleme başvurulmuştur. Katlanılabilir hata oranı \%5, Z değeri 1,96 olmak kabul edilen bu araştırmada örneklem sayısı 382 kadın olarak belirlenmiştir.

\subsection{Verilerin Toplanması ve Analizi}

Araştırmada birincil veriler literatür incelemesi sonucunda daha önce yapılan benzer çalışmalardan elde edilen bilgi ve bulgular baz alınarak oluşturulan anket tekniği kapsamında geliştirilen ölçek aracılığı ile toplanmıştır. Ölçek geliştirme sürecinde, Shenoy (2005), Serçeoğlu, (2014) ve Zağralı ve Akbaba (2015) tarafından gerçekleştirilen önceki çalışmalardan faydalanılmıştır. Ancak, alana yönelik spesifik sorular, araştırmacılar tarafından geliştirilmiştir. 
Araştırmada kullanılan anket ölçeğinin ilk bölümünde; ev kadınlarının sosyodemografik özelliklerini belirlenmesine yönelik kişisel bilgiler (medeni durum, yaş, eğitim durumu, yöresel yemek pişirme sıklığ eğilimi) için sınıflama ölçeği; ikinci bölümde ise ev kadınlarının yöresel yemek üretimi konusundaki düşüncelerinin belirlenmesi kapsamında aralıklı ölçek kullanılmıştır. Ölçeğin ifadeleri "1=Katılmıyorum; 2=Az Katılıyorum; 3=Kısmen Katılıorum; 4=Katıliyorum; 5=Tamamen Katılıyorum" olmak üzere 5'li Likert şeklinde tasarlanmıştır. Anket ölçeği için güvenilirlik katsayısı (Cronbach Alpha) 0,89 olarak tespit edilmiş ve verilerin güvenilir olduğu gözlemlenmiştir. Anket tekniği ile toplanan verilerin analizinde yüzde ve frekans yöntemi, faktör analizi, veri grupları arasında karşılaştırmaların yapılmasında iki değişkenli gruplar için "Bağımsız Örneklem t-Testi" ve çok değişkenli grupların karşılaştırılmasında "Bağımsız Örneklem Tek Yönlü Varyans Analizi" (ANOVA) testi kullanılmıştır.

\section{Bulgular}

Araştırma verilerinin analizi kapsamında ilk olarak Bartın ilinde ikamet etmekte olan ev kadınlarının demografik ve diğer özellikler açısından tanımlayıcı bilgiler, yüzde ve frekans analizi kapsamında Tablo 1'de gösterilen biçimde şekillendiği tespit edilmiştir.

Tablo 1. Ev Kadınlarına Yönelik Tanımlayıcı Bilgiler ( $\mathrm{n}=420)$

\begin{tabular}{|c|c|c|c|c|}
\hline Değişkenler & Gruplar & f & $\%$ & $\begin{array}{c}\text { Kümülatif } \\
\%\end{array}$ \\
\hline \multirow{2}{*}{ Medeni Durum } & Bekar & 87 & 20,7 & 20,7 \\
\hline & Evli & 333 & 79,3 & 100,0 \\
\hline \multirow{4}{*}{ Yaş } & $19-25$ & 36 & 8,6 & 8,6 \\
\hline & $26-32$ & 74 & 17,6 & 26,2 \\
\hline & $33-39$ & 192 & 45,7 & 71,9 \\
\hline & 40 ve üzeri & 118 & 28,1 & 100,0 \\
\hline \multirow{5}{*}{ Eğitim Durumu } & İlkokul & 154 & 36,7 & 36,7 \\
\hline & Ortaokul & 140 & 33,3 & 70,0 \\
\hline & Lise & 53 & 12,6 & 82,6 \\
\hline & Önlisans & 50 & 11,9 & 94,5 \\
\hline & Lisans & 23 & 5,5 & 100,0 \\
\hline \multirow{3}{*}{ Yöresel Yemek Pişirme Sıklığı } & Haftada birkaç kez & 53 & 12,6 & 12,6 \\
\hline & Ayda birkaç kez & 170 & 40,5 & 53,1 \\
\hline & Özel günlerde (düğün, bayram vb.) & 197 & 46,9 & 100,0 \\
\hline \multirow{3}{*}{$\begin{array}{l}\text { Turistler için yöresel yemek } \\
\text { pişirme düşüncesi }\end{array}$} & Evet & 288 & 68,6 & 68,6 \\
\hline & Hayır & 72 & 17,1 & 85,7 \\
\hline & Kararsızım & 60 & 14,3 & 100,0 \\
\hline
\end{tabular}

Katılımcılara yönelik bir çerçeve çizilecek olursa; medeni durum yönünden evliler $(\% 79,3)$, yaş yönünden 33-39 yaş grubu $(\% 71,9)$, eğitim durumu yönünden ilkokul mezunları $(\% 36,7)$, yöresel yemek pişime sıklığı değişkeninde özel günler $(\% 46,9)$ ve turistler için yöresel yemek pişirme düşüncesinde ise evet $(\% 68,6)$ seçenekleri öne çıkmıştır.

Araştırma verilerinin analizi kapsamında ikinci olarak Bartın ilinde ikamet eden ev kadınlarının yöresel yemek üretimine yönelik bakış açılarının ortaya konulması bağlamında faktör analizi öngörülmüştür. Verilerin faktör analizine uygun 
bulunup bulunmadığının belirmesi amacıyla KMO Örneklem Ölçüm Değer Yeterliliği ve Bartlett Kürsellik Testi anlamlılık düzeyi testleri uygulanmıştır. KMO değeri 0,710 ve p değeri 0,000 anlamlılık düzeyinde olduğu görüldüğ̈̈ için verilerin faktör analizine uygun olduğuna karar verilmiştir. Faktör analizi kapsamında dört alt boyut belirlenmiştir. Bu alt boyutlar; üretim, menü, istihdam ve eğitim olarak isimlendirilmiştir. Dört boyut için toplam varyans açıklama yüzdesi 69,230 ve güvenilirlik katsayısı ise 70,5 olarak belirlenmiştir (Tablo 2).

Tablo 2. Ev Kadınlarının Yöresel Yemeklere Bakış Açısına İlişkin Faktör Analizi

\begin{tabular}{|c|c|c|c|c|c|}
\hline Faktör & $\bar{x}$ & $\boldsymbol{\sigma}$ & $\begin{array}{l}\text { Faktör } \\
\text { Yükü }\end{array}$ & $\alpha$ & $\begin{array}{c}\text { Varyans } \\
\text { Açılama } \\
(\%)\end{array}$ \\
\hline Üretim & 3,86 & 1,25 & & & 26.722 \\
\hline Yöresel yemekler üretiminde yerel insanlar çalışmalı. & 3,87 & 1,26 & 0,991 & 0,662 & \\
\hline Yöresel yemekler için pişirme evleri oluşturulmalı. & 3,89 & 1,27 & 0,983 & 0,664 & \\
\hline $\begin{array}{l}\text { Yöresel yemeklerin sunumunda sofra düzeni geleneksel } \\
\text { olmalı. }\end{array}$ & 3,85 & 1,27 & 0,981 & 0,664 & \\
\hline Menü & 3,97 & $\mathbf{0 , 8 2}$ & & & 14,919 \\
\hline Yöresel yemekler mevsimine uygun ürünlerden pişirilmeli. & 3,99 & 1,12 & 0,847 & 0,693 & \\
\hline Yöresel yemekler için özel menüler oluşturulmalı. & 3,85 & 1,19 & 0,674 & 0,678 & \\
\hline $\begin{array}{l}\text { Yöresel yemek menülerinin tanıtımı için yarışmalar } \\
\text { yapılmalı. }\end{array}$ & 4,08 & 1,00 & 0,582 & 0,690 & \\
\hline İstihdam & 3,96 & $\mathbf{0 , 8 0}$ & & & 14,328 \\
\hline Yöresel yemek üretimi için girişimcilik kredisi verilmeli. & 3,89 & 1,00 & 0,785 & 0,696 & \\
\hline Yöresel yemek üretimi için girişimcilik eğitimleri verilmeli. & 3,74 & 1,29 & 0,713 & 0,688 & \\
\hline Yöresel yemekler bize istihdam sağlar. & 4,26 & 1,00 & 0,619 & 0,703 & \\
\hline Ĕgitim & $\mathbf{3 , 4 7}$ & 1,17 & & & 13,262 \\
\hline Yöresel yemek kurslarına katılmak isterim. & 3,41 & 1,38 & 0,825 & 0,694 & \\
\hline $\begin{array}{l}\text { Yöresel yemekleri kaliteli pişiren kişilere yöresel sertifika } \\
\text { verilmeli. }\end{array}$ & 3,53 & 1,50 & 0,710 & 0,690 & \\
\hline \multicolumn{4}{|l|}{ Toplam Cronbach Alpha/Varyans Açıklama (\%) } & $\mathbf{0 , 7 0 5}$ & 69,230 \\
\hline
\end{tabular}

KMO Örneklem Ölçüm Değer Yeterliliği: 0,710

Bartlett Kürsellik Testi (Chi-Square / df / Sig): 2967,169/55/0,000

Araştırmada üçüncü olarak $\mathrm{H}_{1}$ hipotezi olarak test edilmesi öngörülen ev kadınlarının medeni durumları ile yöresel yemeklere bakış açıları arasında anlamlı farklılıkların bulunup, bulunmadığının belirlenmesi kapsamında yönelik Bağımsız Örneklem t-Testi sonuçları Tablo 3'te sunulan şekilde belirlenmiştir: 
Tablo 3. Ev Kadınlarının Medeni Durum Değişkenine Göre Yöresel Yemeklere Bakış Açısı $(n=420)$

\begin{tabular}{|c|c|c|c|c|c|c|}
\hline Değişkenler & Gruplar & $\mathbf{n}$ & $\overline{\boldsymbol{x}}$ & $\sigma$ & $\mathbf{t}$ & $\mathbf{p}$ \\
\hline \multirow{2}{*}{ Üretim } & Bekar & 87 & 3,87 & 1,33 & \multirow[t]{2}{*}{0,076} & \multirow[t]{2}{*}{0,939} \\
\hline & Evli & 333 & 3,86 & 1,23 & & \\
\hline \multirow{2}{*}{ Menü } & Bekar & 87 & 4,00 & 0,73 & \multirow[t]{2}{*}{0,452} & \multirow[t]{2}{*}{0,651} \\
\hline & Evli & 333 & 3,96 & 0,84 & & \\
\hline \multirow{2}{*}{ İstihdam } & Bekar & 87 & 3,95 & 0,81 & \multirow[t]{2}{*}{$-0,134$} & \multirow[t]{2}{*}{0,893} \\
\hline & Evli & 333 & 3,96 & 0,80 & & \\
\hline \multirow{2}{*}{ Eğitim } & Bekar & 87 & 3,47 & 1,25 & \multirow[t]{2}{*}{0,060} & \multirow[t]{2}{*}{0,952} \\
\hline & Evli & 333 & 3,46 & 1,15 & & \\
\hline
\end{tabular}

$*(\mathbf{p}<\mathbf{0 , 0 5})$

Tablo 3'te görüldüğ̈̈ üzere ev kadınlarının medeni durumları ile yöresel yemeklere bakış açılarında anlamlı bir farklılık tespit edilememiştir. Bu sonuçlar kapsamında $\mathrm{H}_{1}$ hipotezi, bu araştırmada kabul edilmemiştir.

Araştırmada dördüncü olarak ev kadınlarının yaşı ile yöresel yemeklere bakış açıları arasında anlamlı farklılıkların bulunup bulunmadığını belirlenmesine yönelik analiz sonuçları, Tablo 4'te sunulan şekilde belirlenmiştir:

Tablo 4. Ev Kadınlarının Yaş Değişkenine Göre Yöresel Yemeklere Bakış Açısı ( $n=420)$

\begin{tabular}{|c|c|c|c|c|c|c|}
\hline Değișkenler & Gruplar & $\mathbf{n}$ & $\overline{\boldsymbol{x}}$ & $\sigma$ & $\mathbf{F}$ & $\mathbf{p}$ \\
\hline \multirow{4}{*}{ Üretim } & $19-25$ & 36 & 4,15 & 1,23 & \multirow{4}{*}{1,431} & \multirow{4}{*}{0,233} \\
\hline & $26-32$ & 74 & 3,68 & 1,36 & & \\
\hline & $33-39$ & 192 & 3,83 & 1,22 & & \\
\hline & 40 ve üzeri & 118 & 3,95 & 1,22 & & \\
\hline \multirow{4}{*}{ Menü } & $19-25$ & 36 & 4,00 & 0,91 & \multirow{4}{*}{0,623} & \multirow{4}{*}{0,601} \\
\hline & $26-32$ & 74 & 4,06 & 0,69 & & \\
\hline & $33-39$ & 192 & 3,91 & 0,83 & & \\
\hline & 40 ve üzeri & 118 & 3,99 & 0,85 & & \\
\hline \multirow{4}{*}{ İstihdam } & $19-25$ & 36 & 4,04 & 0,78 & \multirow{4}{*}{2,361} & \multirow{4}{*}{0,071} \\
\hline & $26-32$ & 74 & 4,08 & 0,79 & & \\
\hline & $33-39$ & 192 & 3,85 & 0,79 & & \\
\hline & 40 ve üzeri & 118 & 4,04 & 0,80 & & \\
\hline \multirow{4}{*}{ Eğitim } & $19-25$ & 36 & 3,43 & 1,42 & \multirow{4}{*}{1,270} & \multirow{4}{*}{0,284} \\
\hline & $26-32$ & 74 & 3,48 & 1,14 & & \\
\hline & 33-39 & 192 & 3,36 & 1,15 & & \\
\hline & 40 ve üzeri & 118 & 3,63 & 1,13 & & \\
\hline
\end{tabular}

$*(\mathbf{p}<\mathbf{0 , 0 5})$

Tablo 4'te görüldüğ̈ü üzere ev kadınlarının yaşı ile yöresel yemeklere bakış açılarında anlamlı bir farklılık tespit edilememiştir. Bu sonuçlar kapsamında test edilmesi öngörülen $\mathrm{H}_{2}$ hipotezi bu araştırmada desteklenmemiştir. 
Araştırmada ev kadınlarının eğitim durumu ile yöresel yemeklere bakış açıları arasında anlamlı farklılıkların bulunup bulunmadığını belirlenmesine yönelik Anova sonuçları Tablo 5'te sunulan şekilde belirlenmiştir:

Tablo 5. Ev Kadınlarının Eğitim Durumu Değişkenine Göre Yöresel Yemeklere Bakış

\begin{tabular}{|c|c|c|c|c|c|c|c|}
\hline & & IÇ1S1 & $=420)$ & & & & \\
\hline Değişkenler & Gruplar & $\mathbf{n}$ & $\bar{x}$ & $\sigma$ & $t / F$ & $\mathbf{p}$ & Tukey \\
\hline \multirow{5}{*}{ Üretim } & İlkokul & 154 & 3,85 & 1,26 & \multirow{5}{*}{0,223} & \multirow{5}{*}{0,926} & \\
\hline & Ortaokul & 140 & 3,90 & 1,21 & & & \\
\hline & Lise & 53 & 3,93 & 1,27 & & & \\
\hline & Önlisans & 50 & 3,73 & 1,22 & & & \\
\hline & Lisans & 23 & 3,89 & 1,56 & & & \\
\hline \multirow{6}{*}{ Menü } & İlkokul & 154 & 3,99 & 0,81 & \multirow{6}{*}{1,847} & \multirow{6}{*}{0,119} & \\
\hline & Ortaokul & 140 & 4,05 & 0,76 & & & \\
\hline & Lise & 53 & 3,77 & 0,89 & & & \\
\hline & Önlisans & 50 & 3,80 & 0,88 & & & \\
\hline & & 23 & 4,11 & 0,78 & & & \\
\hline & Lisans & & & & & & \\
\hline \multirow{6}{*}{ İstihdam } & İlkokul (a) & 154 & 4,07 & 0,73 & \multirow{6}{*}{3,245} & \multirow{6}{*}{$\mathbf{0 , 0 1 2} *$} & \multirow{6}{*}{ a-d } \\
\hline & Ortaokul (b) & 140 & 3,95 & 0,84 & & & \\
\hline & Lise (c) & 53 & 3,83 & 0,80 & & & \\
\hline & & 50 & 3,68 & 0,83 & & & \\
\hline & Onlisans (d) & & & & & & \\
\hline & Lisans (e) & 23 & 4,23 & 0,69 & & & \\
\hline \multirow{5}{*}{ Eğitim } & İlkokul & 154 & 3,57 & 1,11 & \multirow{5}{*}{0,940} & \multirow{5}{*}{0,441} & \\
\hline & Ortaokul & 140 & 3,41 & 1,16 & & & \\
\hline & Lise & 53 & 3,51 & 1,20 & & & \\
\hline & Önlisans & 50 & 3,23 & 1,23 & & & \\
\hline & Lisans & 23 & 3,47 & 1,43 & & & \\
\hline
\end{tabular}

$*(\mathbf{p}<\mathbf{0 , 0 5})$

Tablo 5'te görüldüğü üzere ev kadınlarının eğitim durumu ile yöresel yemeklere bakış açısında üretim, menü ve eğitim alt boyutlarında anlamlı bir farklılık tespit edilememiştir. Bununla birlikte istihdam alt boyutunda ilkokul mezunu ev kadınları $(\overline{\boldsymbol{x}}=\mathbf{4 , 0 4})$ ile önlisans mezunu ev kadınları $(\overline{\boldsymbol{x}}=\mathbf{3 , 6 8})$ arasında anlamlı farklılık 
bulunmuştur. Bu sonuçlar kapsamında $\mathrm{H}_{3}$ hipotezi bu araştırmada kısmen kabul edilmiştir.

Araştırmada ev kadınlarının yöresel yemek pişirme sıklığı ile yöresel yemeklere bakış açıları arasında anlamlı farklılıkların bulunup bulunmadığını belirlenmesine yönelik analiz sonuçları Tablo 6'da yer aldığı biçimde şekillenmiştir:

Tablo 6. Ev Kadınlarının Yöresel Yemek Pişirme Sıklığı Değişkenine Göre Yöresel

Yemeklere Bakış Açısı (n=420)

\begin{tabular}{|c|c|c|c|c|c|c|}
\hline Değişkenler & Gruplar & $\mathbf{n}$ & $\bar{x}$ & $\sigma$ & $\mathbf{t} / \mathbf{F}$ & $\mathbf{p}$ \\
\hline \multirow{3}{*}{ Üretim } & Haftada birkaç kez & 53 & 4,06 & 1,01 & \multirow{3}{*}{0,729} & \multirow{3}{*}{0,483} \\
\hline & Ayda birkaç kez & 170 & 3,83 & 1,25 & & \\
\hline & $\begin{array}{l}\text { Özel günlerde } \\
\text { (düğün, bayram }\end{array}$ & 197 & 3,84 & 1,31 & & \\
\hline \multirow{3}{*}{ Menü } & Haftada birkaç kez & 53 & 3,87 & 0,71 & \multirow{3}{*}{0,611} & \multirow{3}{*}{0,543} \\
\hline & Ayda birkaç kez & 170 & 3,95 & 0,87 & & \\
\hline & $\begin{array}{l}\text { Özel günlerde } \\
\text { (düğün, bayram }\end{array}$ & 197 & 4,01 & 0,80 & & \\
\hline \multirow{3}{*}{ İstihdam } & Haftada birkaç kez & 53 & 3,77 & 0,77 & \multirow{3}{*}{1,727} & \multirow{3}{*}{0,179} \\
\hline & Ayda birkaç kez & 170 & 3,99 & 0,80 & & \\
\hline & $\begin{array}{l}\text { Özel günlerde } \\
\text { (düğün, bayram }\end{array}$ & 197 & 3,98 & 0,80 & & \\
\hline \multirow{3}{*}{ Ĕ̆itim } & Haftada birkaç kez & 53 & 3,55 & 1,09 & \multirow{3}{*}{0,233} & \multirow{3}{*}{0,792} \\
\hline & Ayda birkaç kez & 170 & 3,48 & 1,19 & & \\
\hline & $\begin{array}{l}\text { Özel günlerde } \\
\text { (düğün, bayram }\end{array}$ & 197 & 3,43 & 1,18 & & \\
\hline
\end{tabular}

$*(\mathbf{p}<\mathbf{0 , 0 5})$

Tablo 6'da görüldüğü üzere ev kadınlarının yöresel yemek pişirme sıklığı ile yöresel yemeklere bakış açıları arasında anlamlı bir farklılık tespit edilememiştir. Bu sonuçlar kapsamında test edilmesi öngörülen $\mathrm{H}_{4}$ hipotezi bu kabul görmemiştir.

Araştırmada ev kadınlarının turistler için yemek pişime düşüncesi ile yöresel yemeklere bakış açıları arasında anlamlı farklılıkların bulunup bulunmadığını belirlenmesine yönelik analiz sonuçları Tablo 7'de sunulan biçimde tespit edilmiştir.

Tablo 7'de gösterilen sonuçlar görüldüğü üzere ev kadınlarının turistler için yemek pişime düşüncesi ile yöresel yemeklere bakış açıları arasında da anlamlı bir farklılık bulunamamıştır. Bu sonuçlar kapsamında araştırmada test edilmesi öngörülen $\mathrm{H}_{5}$ hipotezi bu araştırma için desteklenmemiştir. 
Tablo 7. Ev Kadınlarının Turistler İçin Yemek Pişirme Düşüncesi Değişkenine Göre Yöresel Yemeklere Bakış Açısı (n=420)

\begin{tabular}{|c|c|c|c|c|c|c|}
\hline Değişkenler & Gruplar & $\mathbf{n}$ & $\overline{\boldsymbol{x}}$ & $\sigma$ & $\mathbf{t} / \mathbf{F}$ & $\mathbf{p}$ \\
\hline \multirow{3}{*}{ Üretim } & Evet & 288 & 3,79 & 1,28 & \multirow{3}{*}{2,429} & \multirow{3}{*}{0,089} \\
\hline & Hayır & 72 & 3,91 & 1,23 & & \\
\hline & Kararsızım & 60 & 4,17 & 1,08 & & \\
\hline \multirow{3}{*}{ Menü } & Evet & 288 & 3,93 & 0,82 & \multirow{3}{*}{2,537} & \multirow{3}{*}{0,080} \\
\hline & Hayır & 72 & 4,16 & 0,70 & & \\
\hline & Kararsızım & 60 & 3,89 & 0,90 & & \\
\hline \multirow{3}{*}{ İstihdam } & Evet & 288 & 3,96 & 0,80 & \multirow{3}{*}{0,160} & \multirow{3}{*}{0,852} \\
\hline & Hayır & 72 & 3,99 & 0,81 & & \\
\hline & Kararsızım & 60 & 3,91 & 0,76 & & \\
\hline \multirow{3}{*}{ Eğitim } & Evet & 288 & 3,39 & 1,20 & \multirow{3}{*}{2,777} & \multirow{3}{*}{0,063} \\
\hline & Hayır & 72 & 3,75 & 1,02 & & \\
\hline & Kararsızım & 60 & 3,51 & 1,15 & & \\
\hline
\end{tabular}

$*(\mathbf{p}<\mathbf{0 , 0 5})$

Araştırma bulguları kapsamında Bartın ili özelinde ev kadınlarının bakış açısıyla kabul gören yemeklerin öncelik sırası Tablo 8 'te gösterilen biçimde şekillenmiştir:

Tablo 8. Ev Kadınlarının Bakış Açsıyla Bartın İli Yöresel Yemekleri (n=420)

\begin{tabular}{|l|c|c|}
\hline Yemek Adı & f & \% \\
\hline Tarhana & 302 & 72 \\
\hline Yumurtalı Ispıt & 235 & 56 \\
\hline Kuru Yufkalı Tavuk & 227 & 54 \\
\hline Maydanoz Dolması & 226 & 54 \\
\hline Fesleğenli Gözleme & 216 & 51 \\
\hline Halışka & 207 & 49 \\
\hline Pumpum Çorbası & 204 & 49 \\
\hline Kabak Burması & 196 & 47 \\
\hline Zarbana Tatlısı & 185 & 44 \\
\hline Etli Mısır Çorbası & 182 & 43 \\
\hline Amasra Salatası & 181 & 43 \\
\hline Prinçli Mantı & 130 & 31 \\
\hline
\end{tabular}


Tablo 8'de görüldüğü üzere ev kadınlarının bakış açısı ile Bartın ili için yöresel yemeklerde ilk üç sıra "Tarhana", "Yumurtalı Ispıt" ve "Kuru Yufkalı Tavuk" olarak tespit edilmiştir.

\section{SONUÇ VE TARTIŞMA}

Kırsal bölgelerde yerel gıdaların üretimi potansiyel bir kalkınma fırsatıdır. Bununla birlikte kırsal ekonomilerin yerel varlıklarına yönelik ürün veya hizmet sunumları daha fazla yeteneğine bağımlı hale gelmiştir. Bu anlamda yerel yiyeceklerin turistlere teklif edilebilir olması için yetenekli personeller tarafından hazırlanması temel gerekliliktir. $\mathrm{Bu}$ anlamda dünya genelinde dezavantajlı gruplar arasında gösterilen kadınlar, başvurulabilecek önemli bir kaynaktır.

$\mathrm{Bu}$ araştırmada sahil turizmi ve kültür turizmi ile önemli destinasyon olma yolunda ilerleyen Bartın ilindeki ev kadınlarının turistler için yöresel yemek pişime düşüncelerinin ortaya çıarılması ve il özelinde yöresel yemeklere yönelik ev kadınları perspektifinden bir bakış açısı geliştirilmiştir. Ev kadınları perspektifinden yöresel yemekler; menü, üretim, istihdam ve eğitim alt boyutlar önceliğinde şekillendiği tespit edilmiştir.

Üretim boyutunda pişirme evlerinin oluşturulması, yerel insanlar tarafından üretilmesi ve Bartın ilinin geleneklerinde öne çıkan sofra düzeni ile sunumun yapılması; menü boyutunda menülerin tanıtımına yönelik yarışmalar yapılması, mevsimine uygun pişirilme ve özel menüler oluşturması; istihdam boyutunda yöresel yemeklerin kadınlara istihdam alanı sağlayacağı, girişimcilik faaliyetleri ile ilde önem kazanacağı; eğitim boyutunda ise yöresel yemeklere sertifika verilmesi ve gençler için yöresel yemek eğitim kurslarının faydalı olacağı yönündedir.

Yöresel yemeklere yönelik ev kadınlarının bakış açıları ile tanımlayıcı özellikleri (medeni, durum, yaş, eğitim durumu, yöresel yemek pişime sıklığı, turistler için yöresel yemek pişirme düşüncesi) arasında sadece istihdam boyutunda ilkokul mezunları ev kadınları ile önlisans mezunu ev kadınları arasında ortaya çıkmıştır. İlkokul mezunu ev kadınları, önlisans mezunu kadınlara göre yöresel yemek üretiminin kendilerine daha çok istihdam alanı oluşturacağını düşünmektedirler.

Bu sonuçlar göstermektedir ki yöresel yemek üretiminde ev kadınları, Batın ili için potansiyel bir kaynaktır. Bu anlamda kamu idareleri yöneticileri konuyu sahiplenmelidirler. Yöresel yemek üretimi ile ilgili planlama süreci başlatma kararı almalıdırlar. Ayrıca, yerel basın kuruluşları yapacakları haberlerle, sivil toplum kuruluşları örnek projelerle, üniversite eğitim ve yurt içinde ve yurt dişında tanıtım boyutunda rol üstlenebilirler. İl düzeyinde sürdürülebilir bir yöresel yemek üretimi için ev kadılarının yiyecek ve içeceklerin protokol ve görgü kuralları çerçevesinde devamlı ve düzenli bir faaliyet halinde sunulmasına yönelik bilgi ve uygulama becerilerinin geliştirilmesi halinde turizmde önemli çıktılara dönüşebilir. 


\section{KAYNAKÇA}

Alsawafi, A. M. (2016). Exploring the Challenges and Perceptions of Al Rustaq College of Applied Sciences Students Towards Omani Women's Empowerment in the Tourism Sector. Tourism Management Perspectives, 20, 246-250.

Amira, F. (2009). The Role of Local Food in Maldives Tourism: A Focus on Promotion and Economic Development. Unpublished Master Thesis, Auckland University of Technology, New Zealand Tourism Research Institute (NZTRI).

Aslan, H. (2010). Gastronomi Turizminin Turizm Eğitimi Programlarındaki Yeri ve Önemi-Bir Uygulama, Yayınlanmamış Yüksek Lisans Tezi, Selçuk Üniversitesi Sosyal Bilimler Enstitüsü, Konya.

Aslan, Z., Güneren, E. ve Çoban, G. (2014). Destinasyon Markalaşma Sürecinde Yöresel Mutfağın Rolü: Nevşehir Örneği. Journal of Tourism and Gastronomy Studies, 2 (4), 3-13.

Ballı, E. (2016). Gastronomi Turizmi Açısından Adana Sokak Lezzetleri. Journal of Tourism and Gastronomy Studies. 4(Special Issue 1), 3-17.

Bekar, A. ve Belpınar, A. (2015). Turistlerin Gastronomi Turizmine İlişkin Görüşlerinin Milliyetlerine Göre Değerlendirilmesi. Journal of Yasar University, 10 (38), 6478-6554.

Bezirgan, M. ve Koç, F. (2014). Yerel Mutfakların Destinasyona Yönelik Aidiyet Oluşumuna Etkisi: Cunda Adası Örneği. Uluslararası Sosyal Araştırmalar Dergisi, 34 (7) 919-928.

Buczkowska, K. and Poznań, A. (2014). Local Food and Beverage Products as İmportant Tourist Souvenirs. Turystyka Kulturowa, (1), 47-58.

Chang, R. C. Y., Kivela, J. and Mak, A. H. N. (2010). Food preferences of Chinese Tourists. Annals of Tourism Research, 37 (4), 989-1011.

Cömert, M. (2014). Turizm Pazarlamasında Yöresel Mutfakların Önemi ve Hatay Mutfağ Örneği. Journal of Tourism and Gastronomy Studies, 2 (1) 64-70.

Emekli, G. (2006). Coğrafya, Kültür ve Turizm: Kültürel Turizm, Ege Coğrafya Dergisi, (15), 5159.

Fidan, F. ve Nam, D. (2012). Kırsal Turizmde Yeni Dinamikler: Kadın Girişimciler-Taraklı Örneği. KMÜ Sosyal ve Ekonomik Araştırmalar Dergisi, 14 (23), 51-57.

Gheorghe, G., Tudorache, P. and Nistoreanu, P. (2014). Gastronomic Tourism, A New Trend for Contemporary Tourism?. Cactus Tourism Journal, 9 (1), 12-21.

Gürbüz, A. (2002). Yerel Kalkınma Stratejisi İçinde Turizm ve Safranbolu. Bilig-Türk Dünyası Sosyal Bilimler Dergisi, (22), 29-47.

Hatipoğlu, A. (2010). İnançların Gastronomi Üzerine Etkileri Bodrumdaki Beş Yıldızlı Otellerin Mutfak Yöneticilerinin Görüşlerinin Belirlenmesine Yönelik Bir Araştırma. Yayımlanmamış Yüksek Lisans Tezi, Sakarya Üniversitesi Sosyal Bilimler Enstitüsü, Sakarya.

Hatioğlu, A. Zengin, B. Batmaz, O. ve Şengül, S. (2013). Yöresel Yemeklerin, Kırsal Turizm İşletmeleri Mönülerinde Kullanım Düzeyleri: Gelveri Örneği. Uluslararası Sosyal ve Ekonomik Bilimler Dergisi, 3 (1), 06-11.

Kesici, M. (2012). Kırsal Turizme Olan Talepte Yöresel Yiyecek Ve İçecek Kültürünün Rolü. KMÜ Sosyal ve Ekonomik Araştırmalar Dergisi, 14 (23), 33-37. 
Öter, Z. ve Özdoğan, O. N. (2005). Kültür Amaçlı Seyahat Eden Turistlerde Destinasyon İmajı: Selçuk-Efes Örneği. Anatolia: Turizm Araştırmaları Dergisi, 16 (2) 127-138.

Okech, R. N. (2014). Developing Culinary Tourism: The Role of Food as a Cultural Heritage in Kenya.

[Online]<http://globalbizresearch.org/chennai_conference/pdf/pdf/ID_CF412_Formatte d.pdf> Erişim Tarihi: 11.03.2017.

Sağır, A. (2012). Bir Yemek Sosyolojisi Denemesi Örneği Olarak Tokat Mutfağı. Turkish StudiesInternational Periodical For The Languages, Literature and History of Turkish or Turkic, 7 (4), 2675-2695.

Serçeoğlu, N. (2014). Yöre Halkının Mutfak Kültürünü Tanıma Durumunun Tespit Edilmesi: Erzurum İli Örneği. Journal of Tourism and Gastronomy Studies, 2 (4), 36-46.

Shenoy, S. S. (2005). Food Tourism and The Culinary Tourist. Unpublished Doctoral Thesis. The Graduate School of Clemson University, Recreation, and Tourism Management.

Sözbir, F. (2014). Bartın İlinin Sürdürülebilir Potansiyelinin İrdelenmesi. Yayınlanmamış Uzmanlık Tezi, Kültür ve Turizm Bakanlığı Yatırım ve İşletmeler Genel Müdürlüğü, Ankara.

Tayfun, A. ve Tokmak, C. (2007). Tüketicilerin Türk Usulü Fastfood İşletmelerini Tercih Etme Sebepleri Üzerine Bir Araştırma. Elektronik Sosyal Bilimler Dergisi, 6 (22), 169-183.

Türker, N. ve Alaeddinoğlu, F. (2016). From Wine Production to Wine Tourism Experience: The Case of Anatolia, Turkey. Journal of Tourism and Gastronomy Studies, 4 (3), 25-37.

Yurtseven, H. R. ve Kaya, O. (2010). Eko-Gastronomi ve Sürdürülebilirlik. 11. Ulusal Turizm Kongresi Bildiri Kitabı (s.57-65).

Zağralı, E. ve Akbaba, A. (2015). Turistlerin Destinasyon Seçiminde Yöresel Yemeklerin Rolü: İzmir Yarımadası'nı Ziyaret Eden Turistlerin Görüşleri Üzerine Bir Araştırma. Journal of Yasar University, 10 (40), 6633-6644.

$<$ Http://bakka.gov.tr/assets/Planlama1/Bartin_Turizm_Eylem.pdf > Erişim Tarihi: 11 Mart 2017.

$<$ Http://www.bartin.gov.tr/kultur-turizm> Erişim Tarihi: 11 Aralık 2016.

$<$ Http://www.tuik.gov.tr/ilGostergeleri/iller/BARTIN.pdf> Erişim Tarihi: 08 Mart 2017. 